\title{
The Evaluation of Education Faculty Students' Metacognitive Reading Strategies Usage According to Some Variables
}

\author{
Selva Kenanlar and Gulhiz Pilten
}

\begin{abstract}
The purpose of this research, is to determine how the education faculty students' abilities to make use of the strategies of understanding what they read, change depending on the usage of technology. In the research, frequency, percent and standard deviations from the descriptive statistics have been counted. T-test has been established in order to determine however cognitive reading strategies differentiate according to the technology usage factor. At the end of the research; it is found out that the participants' way of reaching the information has been effective on their usage of cognitive reading strategies, the frequency of playing video games on spare times and the usage of technology in daily life had no significant difference on the metacognitive reading strategies.
\end{abstract}

Index Terms-Metacognition, reading strategies, faculty of education.

\section{INTRODUCTION}

Comprehension or reading strategies show how readers perceive a task, steps they take to understand and make sense of what they read [1]. Likewise, these strategies are used by readers to enhance reading comprehension and conquer comprehension failures. Skilled readers automatically use conceptual knowledge (content schemata), text-structure knowledge (formal schemata), and knowledge about text-processing strategies to successfully construct meaning [2].

Meta cognition is defined as "cognition about cognition", or "knowing about knowing". It can take many forms; it includes knowledge about when and how to use particular strategies for learning or for problem solving. There are generally two components of metacognition: knowledge about cognition, and regulation of cognition.

One of the first definitions of metacognition comes from Flavell (1976), who describes it as 'one's knowledge concerning one's own cognitive processes and products or anything related to them'. He also asserts that metacognition includes 'the active monitoring and consequent regulation and orchestration' of information processing activities (Flavell1976:232). Baird (1990:184) uses these ideas to provide the following succinct formulation: 'Meta cognition refers to the knowledge, awareness and control of one's own learning' [3].

Metacognition is an important factor in learning, including

Manuscript received November 10, 2013; revised January 15, 2014.

Selva Kenanlar and Gulhiz Pilten are with University of N. Erbakan, Konya CO 42090, Turkey (e-mail: selvakenanlar@hotmail.com, gulhizp@yahoo.com.tr). activities such as aligning oneself to a learning task, monitoring comprehension, and checking learning outcomes [4]. Students who perform many metacognitive activities tend to attain better learning results than peers who perform few metacognitive activities.

Metacognitively skilled readers not only construct meaning;they also monitor and evaluate texts that they read[5]. They exhibit understanding of what they read for they are conscious of their own mental processes [6].

Metacognition is how one thinks about his or her own thoughts (Harris \& Hodges, 1995). Flavell (1979) believed in the feasibility and desirability of increasing both the quantity and quality of learners' metacognitive knowledge through systematic instruction [7].

Metacognitive strategies differ from cognitive ones in that they span multiple subject areas while cognitive strategies are likely to been capsulated within a subject area so, readers who are meta-cognitively aware know what to do when they face difficulties in learning, they would utilize strategies for recognizing what they should do. Metacognitive strategies indicate one's thinking and can facilitate more learning and developed performance, especially among students who try extremely hard to understand the written context [8].

Furthermore cognitive reading strategies are the actions readers take while interacting directly with the text whereas metacognitive reading strategies are intentional, planned tactics by which learners monitor, identify and remediate their reading [9]. During reading metacognitive processing is expressed through strategies, which are 'procedural, purposeful, effortful, willful, essential and facilitative in nature [10].

Metacognitively skilled readers not only construct meaning; they also monitor and evaluate texts that they read [5]. They exhibit understanding of what they read for they are conscious of their own mental processes [4]. Metacognition is how one thinks about his or her own thoughts (Harris\&Hodges, 1995). Flavell (1979) believed in the feasibility and desirability of increasing both the quantity and quality of learners' metacognitive knowledge through systematic instruction [7].

Metacognitive strategies involve planning, monitoring, and regulation activities that take place before, during, and after any thinking act such asreading. Incontrast, cognitive strategies refer to integrating new material with prior knowledge [4].

Poor readers are less aware of effective strategies and of the counterproductive effects of poor strategies, and are less effective in their monitoring activities during reading. Palincsar (1985:29) suggests that an effective reading 
instruction program requires the identification of complementary strategies that are modeled by an expert and acquired by the learner in a context reinforcing the usefulness of such strategies. Adult and college readers who show evidence of metacognitive deficiencies may be the most aware and capable of monitoring their mental processes while reading. Considers unskilled reading comprehension is one aspect to show the importance and need for training [3]. Unskilled readers can become skilled readers and learners of whole text if they are given instruction in effective strategies and taught to monitor and check their comprehension while reading.

\section{A. Metacognitive Reading Strategies Questionnaire (MRSQ)}

Metacognitive Reading Strategies Questionnaire (MRSQ) developed by Taraban, Kerr and Rynearson (2004) measures the metacognitive strategies used by students when reading. Questionnaire consists of two dimensions; pragmatic and analytical. It is 22 items in total and the first 16 items consist of analytical and the last 6 items consist of pragmatic strategies. Questionnaire is 5-point likert type scale.

Items under analytical strategies mention expresses metacognitive strategies used by students when reading texts. These strategies are those regulating, following and assessing strategies used by students. As an example of the items in analytical strategies dimension of questionnaire, following items can be given: "I make a guess related to information to be presented in the oncoming parts of text" or "I predict how to use information that I acquired from texts after reading it". Items in the second dimension under the title of pragmatic strategies mainly express practical strategies towards further recall [11].

\section{B. The Purpose of Research}

The purpose of this research, is to determine how the education faculty students' reading comprehension skills differs according to their usage of technology level.

The solutions to those questions oriented on the research's purpose have been searched:

- Do opinions concerning pragmatical metacognitive reading strategies show significant difference in terms of, the manner on reaching the information, passing the spare time with video games and technology consume frequency?

- Do opinions concerning analytical metacognitive reading strategies show significant difference in terms of, the manner on reaching the information, passing the spare time with video games and technology consume frequency?

- Do metacognitive reading strategies show significant differences in terms of, the manner on reaching the information, passing the spare time with video games and technology consume frequency?

\section{METHOD}

\section{A. Participants}

This research has been carried out in the Necmettin Erbakan University Ahmet Kelesoglu Education Faculty department of Primary Teacher Education during the education year 2013-2014. 304 students have participated in the research.

\section{B. Data Collection}

Metacognitive Reading Strategies (MRSQ) scale, having been adapted to Turkish language by Cogmen (2008) with the name Ust Bilissel Okuma Stratejileri Olcegi(ÜBOS), has been used.

The scale is consisting of two dimensions as analytical and pragmatical. In the applied measuring tool, the manner of reaching the information, the situation of passing spare times with playing video games and usage frequency of technology in their daily life factors have taken place.

\section{Data Analysis}

SPSS program has been used in the analysis of data. T-test has been used in the analysis of the data. Moreover, percentage, frequency and standard deviations have been counted from the descriptive statistics.

\section{FINDINGS}

The descriptive statistics belonging to the types of participants to reach the information, whether or not passing their spare times by playing video games and frequency of technology usage in their daily life, have been presented in the Table I, Table II and Table III.

TABLE I: DESCRIPTIVE STATISTICS OF THE FACTOR MANNER OF REACHING

\begin{tabular}{|c|c|c|}
\multicolumn{3}{|c|}{ TO INFORMATION } \\
\hline & Frequency & Percent \\
\hline Internet & 261 & 85.9 \\
\hline $\begin{array}{c}\text { PublishedDocuments } \\
\text { (book,newspaperetc.) }\end{array}$ & 43 & 14.1 \\
\hline Total & 304 & 100.0 \\
\hline
\end{tabular}

TABLE II: StATISTICS OF THE FACTOR PASSING His SPARE TIMES PLAYING VIDEO GAMES

\begin{tabular}{|c|c|c|}
\hline & Frequency & Percent \\
\hline Disagree & 38 & 12.5 \\
\hline Agree & 266 & 87.5 \\
\hline Total & 304 & 100.0 \\
\hline
\end{tabular}

TABLE III: STATISTICS OF THE FACTOR USAGE FREQUENCY OF COMPUTER, COMMUNICATION AND MULTIMEDIA TECHNOLOGIES

\begin{tabular}{|c|c|c|}
\hline & Frequency & Percent \\
\hline Sometimes & 9 & 30.9 \\
\hline Always & 21 & 69.1 \\
\hline Total & 30 & 100.0 \\
\hline
\end{tabular}

When we examine Table I, Table II and Table III the $85.9 \%$ of the participants have used internet as a manner of reaching the information, while other $14.1 \%$ has used the written sources. While $12.5 \%$ of the participants didn't pass their spare times with video games; the other $87.5 \%$ passed their spare times with video games. In terms of technology usage frequency $69.1 \%$ of the participants have presented an opinion as always and the other $30.9 \%$ have presented to be sometimes.

The findings belonging to the sub problem;

- Do opinions concerning pragmatical metacognitive reading strategies show significant difference in terms of, 
the manner on reaching the information, passing the spare time with video games and technology consume frequency? It has been presented in the Table IV.

TABLE IV: PRAGMATICAL OVER COGNITIVE STRATEGY T-TEST RESUlTS

\begin{tabular}{|c|c|c|c|c|c|c|c|}
\hline & & $\mathrm{N}$ & $\overline{\bar{X}}$ & Ss & $\mathrm{sd}$ & $t$ & $p$ \\
\hline \multirow{2}{*}{$\begin{array}{l}\text { The type of } \\
\text { accessing } \\
\text { information }\end{array}$} & Internet & 26 & 2.2 & 0.5 & \multirow[t]{2}{*}{53} & \multirow{2}{*}{$\begin{array}{c}2.3 \\
9\end{array}$} & \multirow{2}{*}{$\begin{array}{c}0.02 \\
*\end{array}$} \\
\hline & $\begin{array}{l}\text { Published } \\
\text { Document }\end{array}$ & 43 & 2.0 & $\begin{array}{l}1 \\
0.5 \\
9\end{array}$ & & & \\
\hline \multirow{2}{*}{$\begin{array}{l}\text { Computer } \\
\text { Games }\end{array}$} & Agree & 26 & 2.2 & 0.5 & \multirow[t]{2}{*}{47} & \multirow{2}{*}{$\begin{array}{c}0.7 \\
6\end{array}$} & \multirow[t]{2}{*}{0.45} \\
\hline & Disagree & $\begin{array}{l}6 \\
38\end{array}$ & $\begin{array}{l}3 \\
2.3 \\
0\end{array}$ & $\begin{array}{l}2 \\
0.5 \\
5\end{array}$ & & & \\
\hline \multirow{2}{*}{$\begin{array}{l}\text { Technology } \\
\text { Usage } \\
\text { Frequency }\end{array}$} & Always & 21 & 2.2 & 0.5 & \multirow{2}{*}{$\begin{array}{c}19 \\
3\end{array}$} & \multirow{2}{*}{$\begin{array}{c}1.1 \\
6\end{array}$} & \multirow[t]{2}{*}{0.25} \\
\hline & Sometimes & $\begin{array}{l}0 \\
94\end{array}$ & $\begin{array}{l}2 \\
2.2 \\
9\end{array}$ & $\begin{array}{l}4 \\
0.4 \\
9\end{array}$ & & & \\
\hline
\end{tabular}

The averages of internet and written sources factors, determined as the manner to reach the information have been set as 2.27 and 2.05 respectively. As a result of the t-test which is being applied to test out whether there is significant difference between the two factors, it was calculated as 2.39 and this value, has been found significant in the level 0.05 . That is to say, there is difference in terms of reaching the information during the usage of metacognitive readings usage and this difference is on behalf of the internet usage.

The average of the participants passing their spare times playing video games has been calculated as 2.23 , while those who don't pass playing video games has been calculated as 2.30. As a result of the t-test which is being applied to test out the difference, it was calculated as 0.76 and this value, has not been found significant in the leve 10.05. This case shows that it has no effect whether or not to pass one's spare times playing video games on pragmatical metacognitive reading.

In terms of technology usage frequency the average of participants presenting opinion as always and sometimes has been found as 2.22 and 2.29 respectively. As a result of the ttest which is being applied to test out the difference, it was calculated as 1.16 and this value, has not been found significant in the level 0.05 . This case shows that the frequency of technology usage isn't effective on pragmatical over cognitive reading.

- Do opinions concerning analytical metacognitive reading strategies show significant difference in terms of the manner on reaching the information, passing the spare time with video games and technology consume frequency? (Table V)

TABLE V: ANALytical OVER COGNITIVE STRATEGy T-TeSt RESUlts

\begin{tabular}{|c|c|c|c|c|c|c|c|}
\hline & & $\mathrm{N}$ & $\mathrm{X}^{\overline{-}}$ & $\mathrm{Ss}$ & $\mathrm{sd}$ & $t$ & $p$ \\
\hline The type of & Internet & 261 & 2.37 & 0.83 & 54 & 2.13 & $0.04^{*}$ \\
\cline { 2 - 9 } $\begin{array}{c}\text { accessing } \\
\text { information }\end{array}$ & $\begin{array}{c}\text { Published } \\
\text { Document }\end{array}$ & 43 & 2.05 & 0.93 & & & \\
\hline $\begin{array}{c}\text { Computer } \\
\text { Games }\end{array}$ & Agree & 38 & 2.71 & 0.85 & 48 & 2.95 & $0.00^{*}$ \\
\cline { 2 - 9 } & Disagree & 266 & 2.27 & 0.84 & & & \\
\hline $\begin{array}{c}\text { Technology } \\
\text { Usage }\end{array}$ & Always & 210 & 2.33 & 0.87 & 194 & 0.12 & 0.89 \\
\cline { 2 - 6 } Frequency & Sometimes & 94 & 2.32 & 0.80 & & & \\
\hline
\end{tabular}

The averages of internet and written sources factors, determined as the manner to reach the information have been set as 2.37 and 2.05 respectively. As a result of the t-test which is being applied to test out whether there is significant difference between the two factors, it was calculated as 2.13 and this value, has been found significant in the level 0.05 . That is to say, there is difference in terms of reaching the information during the usage of analytical metacognitive readings usage and this difference is on behalf of the internet usage.

The average of the participants passing their spare times playing video games has been calculated as 2.71 , while those who don't pass playing video games has been calculated as 2.27. As a result of the t-test which is being applied to test out the difference, it was calculated as 2.95 and this value, has been found significant in the level 0.05 . This case shows that it has been effect whether or not to pass one's spare times playing video games on analytical metacognitive reading.

In terms of technology usage frequency the average of participants presenting opinion as always and sometimes has been found as 2.33 and 2.32 respectively. As a result of the ttest which is being applied to test out the difference, it was calculated as 0.12 and this value, has not been found significant in the level 0.05 . This case shows that the frequency of technology usage isn't effective on the analytical metacognitive reading.

- Do metacognitive reading strategies show significant differences in terms of, the manner on reaching the information, passing the spare time with video games and technology consume frequency? (Table VI)

TABLE VI: Over COGNITIVE STRATEGy T-TeSt RESUltS

\begin{tabular}{|c|c|c|c|c|c|c|c|}
\hline & & $\mathrm{N}$ & $X$ & Ss & $\mathrm{sd}$ & $t$ & $p$ \\
\hline \multirow{2}{*}{$\begin{array}{l}\text { The type of } \\
\text { accessing } \\
\text { information }\end{array}$} & Internet & 261 & 2.30 & 0.50 & \multirow{2}{*}{52} & \multirow{2}{*}{2.66} & \multirow{2}{*}{$0.01 *$} \\
\hline & $\begin{array}{l}\text { Published } \\
\text { Document }\end{array}$ & 43 & 2.05 & 0.59 & & & \\
\hline \multirow{2}{*}{$\begin{array}{c}\text { Computer } \\
\text { Games }\end{array}$} & Agree & 266 & 2.24 & 0.55 & \multirow{2}{*}{46} & \multirow{2}{*}{1.81} & \multirow{2}{*}{0.07} \\
\hline & Disagree & 38 & 2.41 & 0.51 & & & \\
\hline \multirow{2}{*}{$\begin{array}{c}\text { Technology } \\
\text { Usage } \\
\text { Frequency }\end{array}$} & Always & 210 & 2.25 & 0.53 & \multirow{2}{*}{195} & \multirow{2}{*}{0.80} & \multirow{2}{*}{0.42} \\
\hline & Sometimes & 94 & 2.30 & 0.48 & & & \\
\hline
\end{tabular}

The averages of internet and written sources factors, determined as the manner to reach the information have been set as 2.30 and 2.05 respectively. As a result of the t-test which is being applied to test out whether there is significant difference between the two factors, it was calculated as 2.66 and this value, has been found significant in the level 0.05 . That is to say, there is difference in terms of reaching the information during the usage of analytical metacognitive readings usage and this difference is on behalf of the internet usage.

The average of the participants passing their spare times playing video games has been calculated as 2.24 , while those who don't pass playing video games has been calculated as 2.41. As a result of the t-test which is being applied to test out the difference, it was calculated as 1.81 and this value, has not been found significant in the level 0.05. This case shows that it has no effect whether or not to pass one's spare times playing video games on analytical metacognitive reading.

In terms of technology usage frequency the average of participants presenting opinion as always and sometimes has been found as 2.25 and 2.30 respectively. As a result of the ttest which is being applied to test out the difference, it was calculated as 0.80 and this value, has been found significant in the level 0.05. This case shows that the frequency of 
technology usage isn't effective on the analytical over cognitive reading.

\section{CONCLUSION}

In this research, the examination of metacognitive reading strategies depending on the technology usage of primary school teaching students, the following consequences have been achieved:

- When we sort out the reaching manners of participants to information it was seen that most of them used internet.

- When the participants were asked if they were playing video games during their spare times, it was seen that most of them play.

- When we examine the usage frequency of the computer, communication and multimedia technologies in the daily life of participants, again we saw that they used the technology frequently.

- In the pragmatical point of view, while their levels of using metacognitive reading strategies; showing significant differences in terms of manners in reaching the technology, but no difference has been found in the frequency of using the technology and playing video

- In the analytical point of view, while their levels of using metacognitive reading strategies; showing significant differences in terms of manners in reaching the technology, and playing video games, but no difference has been found in the frequency of using the technology and playing video games.

- When the total points of participants' metacognitive reading strategies usage levels the consequences similar to the ones in the pragmatical and analytical have been found. While the manner of reaching the information showed significant differences the other two factors, passing their spare times playing video games and technology usage frequency weren' determined.

This study has been carried out only among the primary school teaching students. Consequently the results gained in the research are limited only to the samples of the research. It would be useful to carry out a study in cooperation with a larger sample or different branches (e.g. engineering faculties, educations faculties, etc.) in terms of determining the effect of fondness to technology on the metacognitive reading strategies.

\section{REFERENCES}

[1] M. Singhal, "Reading proficiency, reading strategies, metacognitive awareness and L2 readers," The Reading Matrix, vol. 1, no. 1, 2001.

[2] M. Shih, "Beyond comprehension exercises in the ESL academic reading class," TESOL Quarterly, vol. 26, pp. 289-318, 1992.

[3] F. Cubukcu, "How to enhance reading comprehension through metacognitive strategies," The Journal of International Social Research, 2008.

[4] P. J. Meijera et al., "The development of a questionnaire on metacognition for students in higher education," Educational Research, vol. 55, no. 1, pp. 31-52, 2013.

[5] S. E. Israel, Using Metacognitive Assessments to Create Individualized Reading Instruction, Newark, Del: International Reading Association, 2007.

[6] T, Gunning, Creating Reading Instruction for All Children, Boston: Allyn and Bacon. 1996.

[7] C. A. P. Ilustre, "Beliefs about Reading, Metacognitive Reading Strategies and Text Comprehension among College Students in a Private University," Philippine ESL Journal, vol. 7, pp. 28-47, 2011.

[8] M. R. Ahmadi, H. N. Ismail, and M. K. K. Abdullah, "The Importance of Metacognitive Reading Strategy Awareness in Reading Comprehension," English Language Teaching, vol. 6, no.10, pp. 233-244, 2013.

[9] R. Sheoreya and K. Mokhtarib. (2001). Differences in the metacognitive awareness of reading strategies among native and non-native readers. System 29. [Online]. pp. 431-449. Available: http://www.sciencedirect.com/science/article/pii/S0346251X0100039 2\#

[10] P. A. Alexander and T. L. Jetton, "Learning from text: A multidimensional and developmental perspective," in M. Kamil, P. B. Mosenthal, P. D. Pearson, and R. Barr, Eds., Handbook of reading research, vol. 3, pp. 285-310, Mahwah, NJ: Erlbaum, 2000.

[11] S. Cogmen, "Students' usage of reading strategies in the faculty of education," Adnan Menderes University, Social Science Institue, Pamukkale/Turkey, 2008.
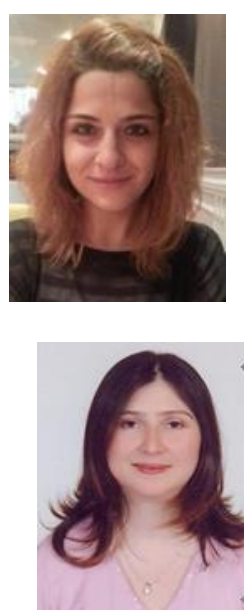

Selva Kenanlar was born in Konyain in 1984. She received her undergraduate education at Selcuk University, Primary Education, in 2006 department in 2009.

She is currently pursuing a doctoral degree at University of Necmettin Erbakan. Her researches focus on Higher Order Thinking. She subsequently served as a faculty member at Necmettin Erbakan University as a research assistant.

Gulhiz Pilten is a Ph.D. She is an assistant professor in the University of N. Erbakan. She has been working at the department of the primary teacher education as a lecturer for 13years. Her major is reading comprehension in primary grades. 